\title{
The Impact of Innovation in Small Industrial Operations to Increased Competitiveness: Empirical Evidence
}

\author{
Luis Aguilera Enriquez, Martha González Adame, Octavio Hernández Castorena \\ Universidad Autonoma de Aguascalientes, Aguascalientes, México
}

\begin{abstract}
The present research work in the Small and Medium Enterprise (SME) and industrial sector explains the impact of the relationship among innovation in the SME operations of Aguascalientes to find the most competitive one; to this end, a questionnaire was intended for managers where the results have been analyzed using the statistical package Structural Equation Modeling Programs (EQS) support which through structural equations has responded to the objective. In this sense, it can be concluded that innovation has a positive relationship with the operations and in turn, this relationship shows a positive impact on the competitiveness of SMEs in Aguascalientes. For this study, a sample of 150 companies has been used.
\end{abstract}

Keywords: innovation, operations, competitiveness, industrial Small and Medium Enterprise (SME)

\section{Introduction}

At present, companies in the industrial sector of SMEs, most often face a number of challenges which rely on significant elements as are the internal operation and innovation that will be implemented by managers and product demand that is increasingly demanding. Therefore, SMEs in order to survive require more innovation and improved efficiency in the manufacture of its products and this will enable organizations to become more competitive (Boix \& Galletto, 2007; Jaffe, Newell, \& Stavins, 2005; Aggeri, 1999). Therefore, the control of internal operations in companies should allow operations managers to be able to improve through innovation which has increased competitiveness of the productive capacity of the organization (Boix \& Galletto, 2007). This means that if a company needs to be increasingly competitive, be aware that you will demand innovation besides responsibility, care, and dedication, a system suited to manufacturing operations and demand for quality products (Vrakking \& Cozijnsen, 1993).

In this regard, it is important to mention that before any implementation of innovation, it should be fully aware of the process flow for operations of a working system to be controlled and it is also relevant supporting documents that have administrative control, in order to facilitate the integration of innovation

Luis Aguilera Enriquez, Ph.D., Departament of Management, Universidad Autonoma de Aguascalientes, Aguascalientes, México.

Martha González Adame, Ph.D., Departament of Management, Universidad Autonoma de Aguascalientes, Aguascalientes, México.

Octavio Hernández Castorena, Ph.D., Departament of Management, Universidad Autonoma de Aguascalientes, Aguascalientes, México.

Correspondence concerning this article should be addressed to Luis Aguilera Enriquez, Ph.D., Universidad Autonoma de Aguascalientes, Departament of Management, Av. Universidad no. 940, Cd Universitaria, Zip Code 20131, México. E-mail: laguiler@correo.uaa.mx. 
activities, no matter how complex it may be in their application to the production system (Vrakking \& Cozijnsen, 1993). Therefore, what matters is that the operations are ready to adopt any innovation, provided you have a positive impact on production operations (Jaffe, Newell, \& Stavins, 2002). It is also important that innovation also considers any internal operating processes closely related to the quality and control of production processes in administrative and operational sense (Jaffe et al., 2002; Brunnermeier \& Cohen, 2003).

Moreover, the competitiveness of industrial enterprises depends on the service you offer and the type of products they develop. The improved performance of the organization therefore will be reflected in factors related to all aspects (technological, organizational, and structural aspects) of business (Doyle, 1994; Kaplan \& Norton, 1992; Oakland, 1993; Browne, Devlin, Rolstadas, \& Andersen, 1997; Cho, Leem, \& Shin, 2008). In this sense, competitive strategies are equally applicable to high-tech companies to SMEs. This means that the value added, labor-intensive, and high-level products enable companies to be competitive (Cho et al., 2008). The companies then in their strategies for improving competitiveness give importance to specialization in specific areas that benefit from an implement of innovation (Rusten \& Bryson, 2007; Rusten, Bryson, \& Aarflot, 2007).

Under behavior, market needs, and competitive positioning of organizations, it requires more commitment, efficiency and attitude of managers, general staff and external areas to focus on giving government greater growth and competition to companies engaged in the manufacture of parts and needs to have operating areas with good production level, for which the operational flexibility is needed in business and can avoid jeopardizing the competitiveness of firms (Sustar, 2004; Nielsen, 1998; Tyson, Petrin, \& Rogers, 1994). Therefore, this research presents an important result which reflects through the statistical treatment with EQS 6.1 software support, the positive effects of innovation in SME operations in Aguascalientes for greater business competitiveness which has worked with a sample of 150 industrial companies through a personalized survey with managers of organizations.

\section{Literature Review}

For businesses in general, innovation as a concept, is linked to the creation and improvement of new products (Vrakking \& Cozijnsen, 1993), therefore, it is considered that the growth of organizations lies in their ability to innovate in all its functional areas, especially in operational areas (Jiménez, 2006), therefore, this innovation refers specifically to improve strategies related to the production process and development of market (Cilleruelo, 2005; Pavón \& Hidalgo, 1997).

According to Cho et al. (2008), it is considered that an operation depends on an operational activity in plasma in which an idea, invention, or recognition from extracted needs a market study, and for which a product, technology, or service useful to customer requirements must be developed (Pavón \& Goodman, 1981). Regarding the review of Machado (1997), it states that "Innovation is frequently repeated by the act of applying new technology; it changes the company to achieve higher profits, growth, sustainability, and competitiveness". Moreover, innovation is the result of a process of analysis and studies focused on improving operations somewhere for production and competition (Velázquez, 2007).

In this sense, any innovation that takes place in part to observe operations and have records of operational activities makes decisions for improvement and innovation for the sake of better control and efficiency 
operations. All the work of analysis should aim to implement actions for improvement and innovation that positively impact operational and administrative activities of firms (Hirch \& Bijaoui, 1985; Teece, 1986). First, before taking any type of innovation in operations, the impact it will have on the internal environmental control SME is considered (Jaffe \& Palmer, 1997). Therefore, in addition to innovation in operations, it is important to also consider the management of waste and auxiliaries to be handled within production operations (Brunnermeier \& Cohen, 2003). It is also necessary to note that in the industry, specifically in SMEs, records obtained through administrative control of operations, will enable managers to make better decisions related to the improvement or innovation in production operations (Khanna \& Anton, 2002; Lee \& Alm, 2004; Da Motta, 2006; Rennings \& Zwick, 2002; Christensen \& Rosenbloom, 1995; Christensen, 1997; Pavitt, 1998).

Therefore, it is necessary to emphasize that all innovation in operations, must be reliable, i.e., a productive operation cannot be unpredictable as this can create an atmosphere of irregularity and the product quality is compromised, but programs even more goods delivery to customers (Van de Kooy, 1983; Cozijnsen, 1989; Vrakking \& Cozijnsen, 1993). In this sense, any innovation to be implemented in organizations must be improved total processes or functional areas as a measure of standardization (Vrakking and Cozijnsen, 1993, Kickert, 1979; Saren, 1984). This means that it is vital that all technology implementation and correct application in operations improvement or innovation activity should be designed to avoid problems of supply of raw materials and production operations management (Bessant \& Grunt, 1986).

It should be mentioned that the companies engaged in the manufacture of parts, constantly updating their methods and strategies to better serve both operations and the dynamics of customer deliveries including after-sales service (Cho et al., 2008). These strategies work for small businesses include the introduction of innovation, improved operational efficiency, and increased productivity (Cho et al., 2008). That is why technological innovations in the industry are competitive factors, affecting mainly the cost of production, flexibility and operations management (Sustar, 2004). Finally, it is important to note that any innovation activity that is integrated into the operations of the SMEs, should impact process improvement and new product development, bearing in mind that the reliability of operations and products allows to be accepted by customers. This means that the product is readily accepted in the market; the entire production system must be safe and reliable with innovation (Ozcelik \& Taymaz, 2004).

\section{Theory and Hypothesis}

Therefore, the activity of innovation in products and processes should be a priority and a challenge for managers (Zhao \& Li, 1997; Wakelin, 1998). In this sense, authors can hypothesize regarding the relationship between innovative activity and operations in industrial SMEs: $\mathrm{H} 1-\mathrm{a}$ best innovation, best in the internal operations of the SMEs.

Finally, in the internal operations of the companies leading organizations to obtain a higher level of competitiveness (Maldonado, Hernandez, \& Aguilera, 2012; Cho et al., 2008; Gardiner, Martin, \& Tyler, 2004), it raises the following hypotheses: $\mathrm{H} 2$ - the control of internal operations impact.

\section{Methodology}

In this research, authors analyze the innovation and its impact on trading activity in the SME of 
Aguascalientes for increased business competitiveness. Because the development of this research was taken from the database reference that offers the Business Directory of Aguascalientes (Siem, 2010) which found that in Aguascalientes, there are 8,661 registered companies, of which 584 are SMEs. The work is empirical and a sample of 150 SMEs is used in Aguascalientes industrial sector which has applied a survey meter type or customized for managers directly responsible for the operations of these organizations.

In the preparation of the measuring instrument, three blocks were used which are described below. Innovation block with 23 items is with Likert scale from 1 to 5 which relates total disagreement to total agreement. The second block of operations is considered with three basic factors: the automation of processes consisting of six items, the reliability of the production process consisting of eight items, the administrative control consisting of eight items and four items of personal development operations (Machorro, Panzi, \& Cabrera, 2007). Finally, for the third block, measuring the level of competitiveness is considered with three basic factors: financial performance consisting of six items, reducing purchasing costs consisting of six items, and the use of technology consisting of six items (Buckley, Pass, \& Prescott, 1988; Chang, Lin, Chen, \& Huang, 2005)

\section{Research Design}

Figure 1 shows the research model prepared for this study.

In this research work, a confirmatory factor analysis (CFA) was conducted in order to assess the reliability and validity of the scales of each of the blocks. Furthermore, authors used a structural equation model (SEM) to check whether the structure of the model is properly designed, and for this, authors used the maximum likelihood method in EQS software version 6.1, and the reliability was evaluated considering the coefficient Cronbach $\alpha$ index and composite reliability (IFC) (Bagozzi \& Yi, 1988).

Table 1 shows that all IFC value exceeded the recommended level of 0.7 , which provides evidence of reliability (Nunnally \& Bernstein, 1994; Hair, Anderson, Tatham, \& Black, 1995) and allows for a fitting model which has obtained the data (S-BX2 $=4870.0469, d f=1,322, p=0.0000$; NFI $=0.895$, NNFI $=0.918$, $\mathrm{CFI}=0.921$, and RMSEA $=0.079)$. All items related factors are significant $(p<0.05)$, the size of all the factor loadings are greater than 0.6 (Bagozzi \& Yi, 1988), and the variance extracted index (EVI) of each pair of constructs is over 0.5 (Fornell \& Larcker, 1981).

Table 2 presents the results obtained describing discriminant validity through two tests. First, with an interval of $95 \%$ confidence level, none of the individual elements of the factors contains the value 1.0 (Anderson \& Gerbing, 1988). Second, extracted variance between each pair of constructs doesn't exceed the corresponding CRI requirements (Fornell \& Larcker, 1981). Therefore, one can conclude that statistical analysis of the results is sufficient evidence of reliability and convergent validity discriminant well.

The diagonal represents the index of variance extracted (IVE), while above the diagonal shows the part of the variance (the correlation to the frame). Below the diagonal, it is presented to estimate the correlation of the factors with a confidence interval of $95 \%$. 


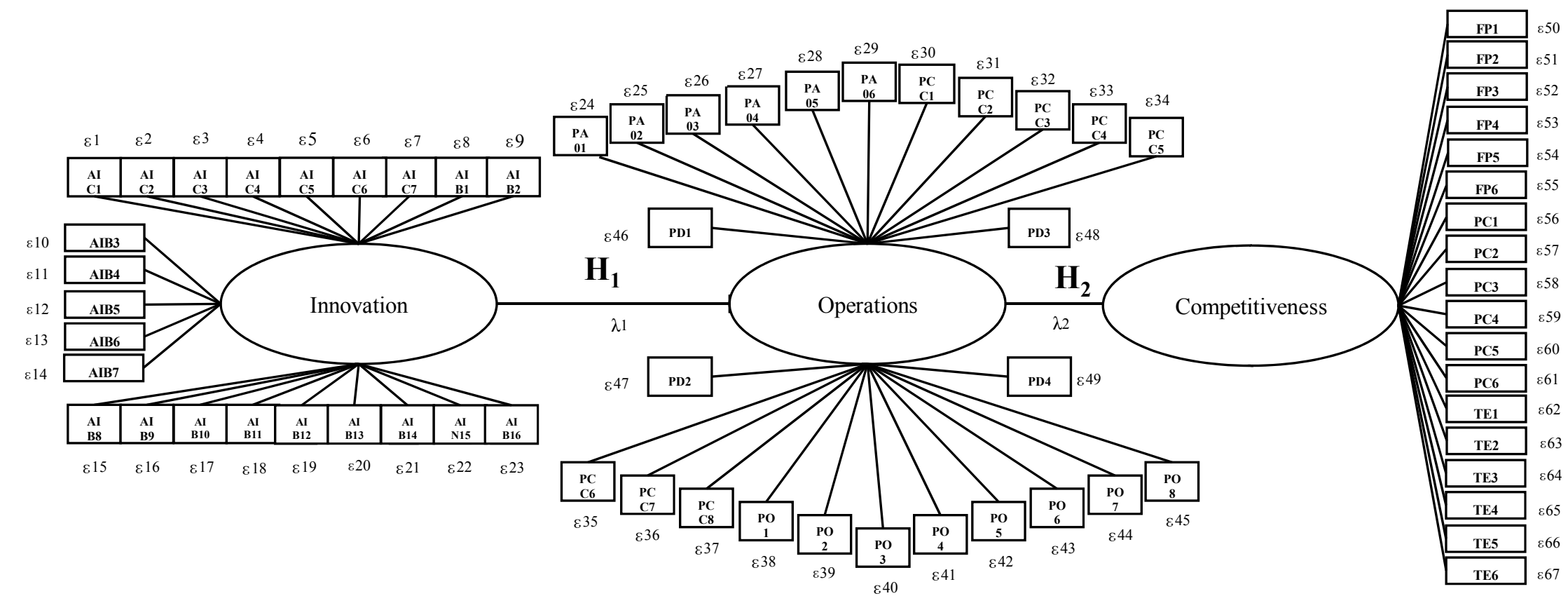

Figure 1. Theorical model. Source: By Machorro et al. (2007), Maldonado et al. (2012), Buckley et al. (1988), and Chang et al. (2005). 
Table 1

Statistical Results of the Theoretical Model

\begin{tabular}{|c|c|c|c|c|c|c|}
\hline Item & Indicator & Robust $t$ value & $\begin{array}{l}\mathrm{CF}>0.6 \\
\text { factorial loading }\end{array}$ & $\begin{array}{l}\text { Alpha } \\
\text { Cronbach }>0.7^{\mathrm{a}}\end{array}$ & $\begin{array}{l}\text { Composite reability } \\
\text { indicator }>0.7^{\mathrm{a}} \text { indice } \\
\text { of fiabilidad compuesta }\end{array}$ & $\begin{array}{l}\text { Average variance } \\
\text { extracted }>0.5^{\mathrm{a}}, \text { indice } \\
\text { of variance extraida }\end{array}$ \\
\hline \multirow{14}{*}{ Innovation (F1) } & AIC1 & 1.000 & 0.797 & \multirow{14}{*}{0.967} & \multirow{14}{*}{0.939} & \multirow{14}{*}{0.523} \\
\hline & $\mathrm{AIC} 2$ & 13.756 & 0.708 & & & \\
\hline & AIC3 & 13.753 & 0.749 & & & \\
\hline & AIC4 & 10.152 & 0.692 & & & \\
\hline & AIC5 & 13.052 & 0.756 & & & \\
\hline & AIB1 & 13.296 & 0.693 & & & \\
\hline & AIB3 & 11.161 & 0.697 & & & \\
\hline & AIB4 & 11.593 & 0.687 & & & \\
\hline & AIB6 & 11.984 & 0.694 & & & \\
\hline & AIB7 & 11.164 & 0.659 & & & \\
\hline & AIB11 & 13.326 & 0.678 & & & \\
\hline & AIB14 & 11.508 & 0.716 & & & \\
\hline & AIB15 & 10.521 & 0.697 & & & \\
\hline & AIB16 & 10.152 & 0.696 & & & \\
\hline \multirow{24}{*}{ Operations (F2) } & $\Sigma$ & & 9.919 & \multirow{24}{*}{0.963} & \multirow{24}{*}{0.969} & \multirow{28}{*}{0.504} \\
\hline & PA1 & 1.000 & 0.729 & & & \\
\hline & PA3 & 13.925 & 0.703 & & & \\
\hline & PA4 & 8.602 & 0.628 & & & \\
\hline & PA5 & 11.670 & 0.736 & & & \\
\hline & PA6 & 11.704 & 0.737 & & & \\
\hline & PCC1 & 14.367 & 0.744 & & & \\
\hline & PCC2 & 16.450 & 0.788 & & & \\
\hline & PCC3 & 15.482 & 0.852 & & & \\
\hline & $\mathrm{PCC} 7$ & 15.153 & 0.776 & & & \\
\hline & PCC8 & 13.184 & 0.698 & & & \\
\hline & PO1 & 16.256 & 0.857 & & & \\
\hline & $\mathrm{PO} 2$ & 15.618 & 0.869 & & & \\
\hline & PO3 & 15.163 & 0.867 & & & \\
\hline & PO4 & 16.427 & 0.884 & & & \\
\hline & PO5 & 15.785 & 0.878 & & & \\
\hline & PO6 & 15.920 & 0.884 & & & \\
\hline & PO7 & 11.200 & 0.630 & & & \\
\hline & PO8 & 14.702 & 0.835 & & & \\
\hline & PD1 & 12.021 & 0.692 & & & \\
\hline & PD2 & 12.055 & 0.699 & & & \\
\hline & PD3 & 10.671 & 0.654 & & & \\
\hline & PD4 & 10.407 & 0.655 & & & \\
\hline & $\Sigma$ & & 16.795 & & & \\
\hline \multirow{4}{*}{$\begin{array}{l}\text { Competitiveness } \\
\text { (F3) }\end{array}$} & FP1 & 1.000 & 0.721 & \multirow{4}{*}{0.963} & \multirow{4}{*}{0.945} & \\
\hline & FP2 & 24.598 & 0.724 & & & \\
\hline & FP3 & 25.944 & 0.722 & & & \\
\hline & FP4 & 22.805 & 0.794 & & & \\
\hline
\end{tabular}


Table 1 continued

\begin{tabular}{|c|c|c|c|c|c|}
\hline Item & Indicator & Robust $t$ value & $\begin{array}{l}\mathrm{CF}>0.6 \\
\text { factorial loading }\end{array}$ & $\begin{array}{l}\text { Alpha } \\
\text { Cronbach }>0.7^{\mathrm{a}}\end{array}$ & $\begin{array}{ll}\text { Composite reability } & \text { Average variance } \\
\text { indicator }>0.7^{\mathrm{a}} \text { indice } & \text { extracted }>0.5^{\mathrm{a}}, \text { indice } \\
\text { of fiabilidad compuesta of variance extraida }\end{array}$ \\
\hline \multirow{14}{*}{$\begin{array}{l}\text { Competitiveness } \\
\text { (F3) }\end{array}$} & FP5 & 16.443 & 0.699 & & \\
\hline & FP6 & 14.109 & 0.679 & & \\
\hline & $\mathrm{PC} 2$ & 14.012 & 0.658 & & \\
\hline & PC3 & 15.058 & 0.676 & & \\
\hline & PC4 & 15.118 & 0.691 & & \\
\hline & PC5 & 12.871 & 0.693 & & \\
\hline & PC6 & 12.753 & 0.699 & & \\
\hline & TE1 & 21.069 & 0.797 & & \\
\hline & TE2 & 14.184 & 0.695 & & \\
\hline & TE3 & 15.345 & 0.695 & & \\
\hline & TE4 & 14.066 & 0.690 & & \\
\hline & TE5 & 12.053 & 0.696 & & \\
\hline & TE6 & 18.502 & 0.729 & & \\
\hline & $\Sigma$ & & 12.058 & & \\
\hline
\end{tabular}

Notes. S-BX2 $(\mathrm{df}=1,322)=4,870.0469, p<0.0000, \mathrm{NFI}=0.895, \mathrm{NNFI}=0.918, \mathrm{CFI}=0.921$, and RMSEA $=0.079 ;{ }^{\mathrm{a}}$

Costreñidos parameters that value in the identification process; *** $p<0.001$ factor loading of each indicator.

Table 2

Validity of Discriminate Measure of the Theoretical Model

\begin{tabular}{|c|c|c|c|c|c|}
\hline Variables & & Innovation & & Operations & Competitiveness \\
\hline \multirow{2}{*}{ Innovation (F1) } & \multirow{2}{*}{\multicolumn{2}{|c|}{0.523}} & & $(0.281)^{2}$ & $(0.442)^{2}$ \\
\hline & & & & 0.079 & 0.195 \\
\hline \multirow{2}{*}{ Operations (F2) } & 0.281 & 0.043 & & \multirow{2}{*}{0.590} & $(0.319)^{2}$ \\
\hline & 0.195 & 0.367 & & & 0.102 \\
\hline \multirow{2}{*}{ Competitiveness (F2) } & 0.442 & 0.047 & 0.319 & 0.044 & \multirow{2}{*}{0.504} \\
\hline & 0.348 & 0.536 & 0.231 & 0.407 & \\
\hline
\end{tabular}

\section{Results}

SEM was performed to check the structure of the conceptual model and the hypotheses posed, using the blocks contained in the instrument of assessment which are described as follows: first block consisting of variables measuring innovation, the second block variables measuring operations, and the last block consisting of the variables related to the competitiveness of the company. The nomological validity of the model was tested by performing the Chi-square, in which the theoretical model was compared with the measurement model (Anderson \& Gerbing, 1988; Hatcher, 1994).

The assumptions made in this research show favorable results described below: with respect to the first hypothesis H1, the results presented in Table $3(\beta=0.418, p<0.000)$, indicating that the innovation has a positive impact on the internal operations of SME companies. Regarding the second hypothesis $\mathrm{H} 2$ results $(\beta=$ $0.458, p<0.000)$, it indicates that the internal operations have a positive impact on the competitiveness of SMEs. 
Table 3

\begin{tabular}{|c|c|c|c|c|}
\hline Hypothesis & Structural relation & $\begin{array}{l}\text { Standardized } \\
\text { coefficient }\end{array}$ & $\begin{array}{l}\text { Robust } \\
t \text { value }\end{array}$ & $\begin{array}{l}\text { Measure of fit model } \\
\text { adjust }\end{array}$ \\
\hline $\begin{array}{l}\text { H1: a best innovation, best in the } \\
\text { internal operations of the SMEs. }\end{array}$ & $\begin{array}{l}\text { Innovation } \longrightarrow \\
\text { Operations } \\
\text { Innovation } \longrightarrow\end{array}$ & $0.418^{* * *}$ & 12.189 & $\begin{array}{l}\text { S-BX2 = 4,803.7376, } \\
d f=1,304 \\
p=0.0000\end{array}$ \\
\hline $\begin{array}{l}\text { H2: the control of internal } \\
\text { operations impact. }\end{array}$ & Competitiveness & $0.458^{* * *}$ & 12.947 & $\begin{array}{l}\text { NFI = 0.897; } \\
\text { NNFI = 0.918; } \\
\text { CFI = 0.922; } \\
\text { RMSEA }=0.078\end{array}$ \\
\hline
\end{tabular}

\section{Conclusions}

For the company's SME industry today, it is important to consider their growth strategies, improve and innovate their products, the marketing thereof, the acquisition of machinery and equipment that have a direct relationship with the manufacture of products that the company offers to the market and improves both supply systems and administrative activities among staff involved with the operations and growth of the company. In addition, these businesses are aware in several senses of the risks of innovation in terms of costs and investments, the need for innovation systems, as this creates problems of administration and finance. In this situation, companies fear the economic problems of the environment, lack of information by the market behavior and counseling regarding technological innovation and of course, to the distrust of outsourcing services.

Regarding the operations into the enterprises, the SMEs shows a special interest in adopting automated equipment that is controlled by specialized software to process reliability and customer needs. Regardless of which currently has regular mechanical equipment, it has been keen to automate and control technological systems commensurate with the ability of the company or the nature of the production processes.

Administrative systems and business operations are strengthened by implementations of documents that enable better control and monitoring records of both production and productivity of the operating system. This will also allow companies to have administrative controls which are considered to already have a maintenance control, quality control through statistical systems and production control in more detail. Of course, those companies gradually have the advantage of having trained personnel for these functions.

In terms of competitiveness, companies show favorable results in terms of financial controls and cost control which then generate that companies have serious problems in operation in the environment in which they develop. In this regard, companies show a special interest in controlling important aspects such as cost control in the supply of raw material, transport management in ancillary material inputs, and handling costs of production operations.

Finally, it is important to note that the industrial companies in this research show an interest in developing space technology in order to improve its products and its internal operations, and for this, managers are aware that they need computer and machinery that have the capacity and flexibility to adapt to any challenge that is presented in the market and customer needs.

\section{References}

Aggeri, F. (1999). Environmental policies and innovation: A knowledge based perspective on cooperative approaches. Research Policy, 28, 699-717. 
Anderson, J., \& Gerbing, D. (1988). Structural equation modeling in practice: A review and recommended two-step approach. Psychological Bulletin, 13(1), 411-423.

Bagozzi, R. \& Yi, Y. (1988). On the evaluation of structural equation models. Journal of the Academy of Marketing Science, 16(1), 74-94.

Bessant, J., \& Grunt, M. (1986). Management and manufacturing innovation in the United Kingdom and West Germany. Aldershot: Gower.

Boix, R. \& Galletto, V. (2007). The new map of the industrial districts in Spain and the comparison with Italy and the United Kingdom: Improving international comparison of industrial districts with common methodologies. Proceedings from Regional Studies Association International Conference. Lisbon, Portugal.

Browne, J., Devlin, J., Rolstadas, A., \& Andersen, B. (1997). Performance measurement: the ENAPS approach. The International Journal of Business Transformation, 1(2), 73-84.

Brunnermeier, S. \& Cohen, M. (2003). The determinants of environmental innovation in US manufacturing industries. Journal Environmental Economics and Management, 45, 278-293.

Buckley, J. P., Pass, L. C., \& Prescott, K. (1988). Measures of international competitiveness: A critical survey. Journal of Marketing Management, 4(2), 175-200.

Chang, S. C., Lin, R. J., Chen, J. H., \& Huang, L. H. (2005). Manufacturing flexibility and manufacturing proactiveness: Empirical evidence from the motherboard industry. Industrial Management \& Data System, 105(8), 1115-1132.

Christensen, C. M. (1997). The innovator's dilemma, when new technologies cause great firms to fail. Boston: Harvard Business School Press.

Christensen, C. M., \& Rosenbloom, R. S. (1995). Explaining the attacker's advantage: technological paradigms, organizational dynamics, and the value network. Research Policy, 24, 233-257.

Cho, Y. J., Leem, C. S., \& Shin, K. T. (2008). The relationships among manufacturing innovation, competitiveness, and business performance in the manufacturing industries of Korea. International Advanced Manufacturing Technology, 38(1), 840-850.

Cilleruelo, E. (2005), Compendio de definiciones del concepto "Innovación" realizadas por Autores relevantes: diseño hibrido actualizado del concepto, Bilbao: Escuela Técnica Superior de Ingeniería de Bilbao, pp. 66.

Cozijnsen, A. J. (1989). Het Innovatievermogen van Politie-organisaties; Onderzoek naar de mogelijkheden van een non-profit organisatie om complexe vernieuwingen succesvol door te voeren. Deventer: Kluwer Bedrijfswetenschappen.

Da Motta, R. S. (2006). Analyzing the environmental performance of the Brazilian industrial sector. Ecological Economics, 57, 269-281.

Doyle, P. (1994). Setting business objectives and measuring performance. European Management Journal, 12(2), 123-132.

Fornell, C., \& Larcker, D. (1981). Evaluating structural equation models with unobservable variables and measurement error. Journal of Marketing Research, 18(1), 39-50.

Gardiner, B., Martin, R., \& Tyler, P. (2004). Regional competitiveness, productivity and economic growth across the European regions. Studia, 38(9), 1045-1067.

Hair, J. F., Anderson, R. E., Tatham, R. L., \& Black, W. C. (1995). Multivariate data analysis with readings. New York: Prentice-Hall.

Hatcher, L. (1994). A step by step approach to using the SAS system for factor analysis and structural equation modeling. Cary: SAS Institute Inc..

Hirch, S., \& Bijaoui, I. (1985). R\&D, intensity and export performance: A micro view. Weltwirtschaftliches Archiv, 121, $238-251$.

Jaffe, A., \& Palmer, K. (1997). Environmental regulation and innovation: A panel data study. The Review of Economics and Statics, 79(4), 610-619.

Jaffe, A. B., Newell, R. G., \& Stavins, R. N. (2005). A tale of two market failures: Technology and environmental policy. Ecological Economics, 54, 164-174.

Jaffe, A. B., Newell, R. G., \& Stavins, R. N. (2002). Environmental policy and technological change. Environmental and Resource Economics, 22, 41-69.

Jiménez, A. E. (2006). Diseño y Aplicación de una Metodología para la elaboración de la estratégica tecnológica en la Empresa de Desmonte y Construcción de Pinar del Rio (Tesis en opción al grado científico de Máster en Ciencias Económicas, Pinar del Rio, Universidad de Pinar del Rio, p.7).

Kaplan, R. S., \& Norton, D. P. (1992). The balanced scorecard-measures that drive performance. Hardvard Business Review, 1(1), 71-79. 
Khanna, M., \& Anton, W. R. Q. (2002). Corporate environmental management: Regulatory and market-based incentives. Land Economics, 78, 539-558.

Kickert, W. J. M. (1979). Organization of decision-making: A systems-theoretical approach. Amsterdam: North-Holland Publishing Company.

Lee, A., \& Alm, J. (2004). The clean air act amendments and firm investment in pollution abatement equipment. Land Economics, $80(2), 433-447$.

Machado, F. M. (1997). Gestión Tecnológica para un salto en el Desarrollo Industrial. Madrid: CDTI-CSIC.

Machorro, R. A., Panzi, U. M., \& Cabrera, Z. G. (2007). Problemas que afectan la administración adecuada de los recursos tecnológicos en las pequeñas y medianas empresas. Academia Journals, 1(1), 1-7.

Maldonado, G. G., Hernandez, C. O., \& Aguilera, E. L. (2012). The relationship between production process and competitiveness level in Mexican SME's: An empirical study. Advances in Competitiveness Research, 20(3), 3-15.

Nielsen, K. (1998). Industrial policy and European integration: The dynamics of change of industrial policy in central and eastern Europe in response to domestic needs and external requirements. Esbjerg: South Jutland University Press.

Nunnally, J. C., \& \& Bernstein, I. H. (1994). Psychometric Theory (3rd ed.). New York: McGraw-Hill.

Oakland, J. S. (1993). Total quality management-The route to improving performance. Oxford : Butterworth-Heinemann.

Ozcelik, E., \& Taymaz, E. (2004). Does innovativeness matter for international competitiveness in developing countries? Research Policy, 33, 409-424.

Pavitt, K. L. R. (1998). Technologies, products and organization in the innovating firm: What Adam Smith tells us and Joseph Schumpeter doesn't. Industrial and Corporate Change, 7, 433-452.

Pavón, J. \& Goodman, R. (1981). Proyecto MODELTEC. La Planificación del Desarrollo tecnológico. Madrid: CDTI-CSIC.

Pavón, J., \& Hidalgo, A. (1997). Gestión e Innovación. Un Enfoque Estratégico. Madrid: Piramide.

Rennings, K., \& Zwick, T. (2002). The employment impact of cleaner production on the firm level-Empirical evidence from a survey in five European countries. International Journal of Innovation Management (IJIM), 6(3), 319-342.

Rusten, G., \& Bryson, J. R. (2007). The production and consumption of industrial design expertise by small and medium-sized firms: Some evidence from Norway. Geografiska Annaler: Series B, Human Geography, 89(1), 75-87.

Rusten, G., Bryson, J. R., \& Aarflot, U. (2007). Places through product and products through places: industrial design and spatial symbols as sources of competitiveness. Norsk Geografisk Tidsskrift-Norwegian Journal of Geography, 61(3), 133-144.

Saren, M. A. (1984). A classification and review of models of the intra-firm innovation process. Research and Development management, 14, 14.

Siem, (2010). Sistema de información Empresarial Mexicana. Secretaría de Economía, México. Retrieved from $\mathrm{http}: / / \mathrm{www} \cdot$ siem.gob.mx/siem/

Sustar, B. (2004). Industrial structure and international competitiveness of post-communist Slovenia. Post-Communist Economies, $16(1), 73-88$

Teece, D. J. (1986). Profiting from technological innovation: Implications for integration, collaboration, licensing and public policy. Ricerche Economiche, 40, 607-643.

Tyson, L. d'A., Petrin, T., \& Rogers, H. (1994). Promoting enterpreneurship in Eastern Europe. Small Business Economics, 6(3), 165-184.

Van de Kooy, B. J. G. (1983). Management van innovatie: de mens als vergeten dimensie. Deventer: Kluwer Bedrijfswetenschappen.

Velázquez, L. G. (2007). Porque y como innovar en las pequeñas y medianas empresas. Retrieved from http://www.gestiopolis.com

Vrakking, W. J., \& Cozijnsen, A. J. (1993). Monitoring the quality of innovation processes and innovation successes. Journal of Strategic Change, 2(1), 65-81.

Wakelin, K. (1998). Innovation and export behavior at the firm level. Research Policy, 26, 829-841.

Zhao, H., \& Li, H. (1997). R\&D, and export: An empirical analysis of Chinese manufacturing firms. Journal of High Technology Management Research, 8, 89-105. 